Int. J. Electrochem. Sci., 11 (2016) 4878 - 4891

International Journal of

ELECTROCHEMICAL

SCIENCE

www.electrochemsci.org

\title{
Methylene Blue decolorization and Mineralization by Means of Electrochemical Technology at Pre-pilot Plant Scale: Role of the Electrode Material and Oxidants
}

\author{
Juliana Patrícia Souza Duarte Pontes, Patrícia Rachel Fernandes da Costa, Djalma Ribeiro da Silva, \\ Sergi Garcia-Segura, Carlos Alberto Martínez-Huitle
}

Laboratório de Eletroquímica Ambiental e Aplicada (LEAA), Institute of Chemistry, Federal University of Rio Grande do Norte, Lagoa Nova, CEP 59078-970, Natal, RN, Brazil

*E-mail: carlosmh@quimica.ufrn.br

doi: $10.20964 / 2016.06 .2$

Received: 21 February 2016 / Accepted: 20 March 2016 / Published: 4 May 2016

In this work, a synthetic effluent containing methylene blue has been treated by electrochemical oxidation (EO) process at pre-pilot plant scale using a filter-press electrochemical cell reactor. Electrochemical experiments were carried out using Ti/Pt and $\mathrm{Ti} / \mathrm{IrO}_{2}-\mathrm{Ta}_{2} \mathrm{O}_{5}$ anodic materials in the presence or absence of chloride ions to study the influence on the decolorization and mineralization of the different oxidant species electrogenerated in situ. The electrochemical experiences have been carried out at different applied current densities $\left(j=20,40\right.$ and $\left.60 \mathrm{~mA} \mathrm{~cm}{ }^{-2}\right)$ to evaluate the effect of this controlling parameter on the degradation efficiency and the operational energy consumption. Under optimal treatment conditions of $40 \mathrm{~mA} \mathrm{~cm}^{-2}$ in $0.05 \mathrm{M}$ of $\mathrm{Na}_{2} \mathrm{SO}_{4}$ at $\mathrm{pH} 6.0$, solutions of 100 $\mathrm{mg} \mathrm{L}^{-1}$ of methylene blue were completely decolorized obtaining $86.0 \%$ of COD abatement after 360 min of electrolysis. The determination of energy consumption allowed to estimate operational costs about 13.36 US $\$ \mathrm{~m}^{-3}$. The results obtained provide valuable information regarding the EO process scaling-up, aiming the application of electrochemical technologies to treat actual effluent at real scale.

Keywords: dyes, dimensional stable anodes (DSA), wastewater treatment, anodic oxidation, electrochemical advanced oxidation processes (EAOPs),

\section{FULL TEXT}

C) 2016 The Authors. Published by ESG (www.electrochemsci.org). This article is an open access article distributed under the terms and conditions of the Creative Commons Attribution license (http://creativecommons.org/licenses/by/4.0/). 